\title{
植物性色素がシロネズミの血清および肝臓 コレステロール値に及ぼす影響
}

辻啓介, 辻悦子, 鈴木慎次郎

国立栄湌研究所栄養生理部

\section{Effects of Plant Pigments on Serum and Liver Cholesterol Levels in Rats}

Keisuke Tsuji, Etsuko Tsuji, Shinjiro Suzuki

Division of Physiology, The National Institute of Nutrition

The effects of several plant pigments or its derivatives on cholesterol metabolism in rats were studied.

1. Serum and liver cholesterol depressing activity of $\mathrm{Cu} \cdot \mathrm{Na} \cdot \mathrm{chlorophyllin,} \mathrm{a} \mathrm{water} \mathrm{soluble} \mathrm{derivative}$ of chlorophyll, was markedly confirmed in the hypercholesterolemic rats placed on the diet containing $1 \%$ cholesterol and $0.25 \%$ bile salts.

2. However, no significant alterations in the level of serum cholesterol were shown in rats fed a cholesterol free, $\mathrm{Cu}-\mathrm{Na}$-chlorophyllin diet as compared with the control group. In such condition, a slight decrease in the liver cholesterol level was observed by $\mathrm{Cu}-\mathrm{Na} \cdot \mathrm{chlorophyllin}$ supplement.

3. The hypocholesterolemic activities of $\beta$-carotene, rutin, quercetin and xanthophyll were not recognized.

Jap. J. Nutr. 33 ( 4 ) 153 159 (1975)

従来, 動脈硬化症を防ぐ目的で, 血中コレステロール低下作用物質が多数食品成分から見出されてきてい る。これらの物質にはリノール酸やエリタデニンのように生体内に吸収されて初めて効果を発揮するものもあ るが, 一方塩化第 2 鉄の上うに消化管内で胆汁酸塩と結合しその吸収を妨げる結果血漿コレステロール值の上 升を抑制するものる見出されている1)。さらに消化管内でコレステロールと特異的に結合するトマチン2) とも塩 化第 2 鉄同様の作用が報告されており，これらの物質は消化管内を未吸収の状態で通過中に外因性もしくは腸 肝循環中の内因性の胆汁酸やコレステロールの吸収や再吸収を阻害することにより, 血中や肝コレステロール の減少をもたらすものと推定されている。また著者らも，難消化性の多糖頪であるコンニャクマンナンに32 5) 同様の作用機序を認め報告している。

難消化性, 難吸収性の食品成分について, 生体内で利用されにくいところから非栄養成分とみなされてきた が，消化管内に批りる他の栄養素や生理活性物質あるいは腸肝循環性因子との相互作用を介して生体に影響を 与える可能性を考虑しなければならない。例光ば日常摂取している食品中の天然色素や合成食用色素について はカロチンやルチンなどの生理活性を有するるのを除くと, 主に着色による食欲増進の利点だけが評価されて きたが，これは大部分の色素が難吸収性であることにと原因があった。しかし1970年に Subba Rao らは, カ レー粉の色素であるクルクミンが糞中へのコレステロールと胆汁酸の排泄促進により血中コレステロール值の 上昇を抑制することを見出しており非栄養成分の植物性色素にもコレステロール代謝に関与しているるのが あることを明らかにした。

金田らは海藻をコレステロール摂取シロネズミに与えると, 緑藻では血中コレステロールの上昇抑制作用が 強いが, 紅藻や褐藻ではこの作用が弱いことを報告しだ78)。また Kondratiev ${ }^{9)}$ はクロレラを人に大量摂取さ 
せたところ血中コレステロールを低下させたが，脱色クロレラでは，この効果が失われることを見出した。こ れらの実験成績は緑色色素である葉緑素に脱コレステロール作用があることを示唆するすのと思われるが，従 来葉緑素とコレステロールとの関倸を追求した研究は少なく，またその結論にもかなり相違があった ${ }^{10) ~ 12) 。 ~}$ そこでわれわれはクロロフィリンを中心に数種の植物性色素についてシロネズミの血清拉よび肝コレステロー ルに及ぼす影響を検討し若干の知見を得たので報告する。

\section{実 験 方 法}

供試試料：銅クロロフィリンナトリウムは日清化学郴製の食品添加物用で, 乾物当り純度 $99.7 \%$ のものを使 用した。 $\beta$-カロチンは田辺製薬㑣，ルチン，クェルチン，キサントフィルは東京化成工業㑣の製品を使用し た。

実験動物：全実験を通じてSprague-Dawley系ラット（日本クレア(陎）を用いた ${ }^{13)}$ 。各実験に用いたラット の性，頭数，実験開始時の平均初体重，飼育期間は実験結果の各表の脚注に記した。

飼料：基本飼料の組成は表 1 のと扮りである。飼料中油脂源として大豆油とラードの比率が $6: 8$ と $1: 10$ の 2 種類の飼料を使用した。前者を標準飼料 1 , 後者

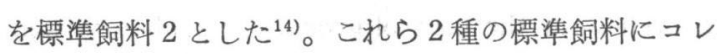
ステロール $1 \%$ と胆汁酸塩0. $25 \%$ を各々添加し, コレ ステロール飼料 1 と 2 とした。植物性色素は $0.5 \sim 2 \%$ をコレステロール飼料, または標準飼料（実験 4 ）の 蔗糖と置換した。

飼育方法と動物の処理：飼料と水は自由に摂取させ， 隔日ごとに摂食量と体重を測定した。実験期間終了後, 実験 1 から 5 では 1 夜絶食させ, 実験 6 では絶食させ ることなく断首採血し，常法に従い遠心分離して血清 を得た。また肝臟および内容物を含む盲腸をただちに 摘出し，沪紙で血を奴って重量を測定した。

コレステロールの定量方法 : 血清コレステロール値 は既報 ${ }^{13)}$ の上うに Sobel と Fernandez の方法 ${ }^{15)}$ に 準じて定量した。また肝コレステロール值は Sperry と Webb の方法 ${ }^{16)}$ に従って抽出, ジギトニン処理を 施した後, 形成したジギトニドを氷酭酸に溶解し以下 Table 1 Composition of standard diets

\begin{tabular}{|c|c|c|}
\hline Components & $\begin{array}{c}\text { Standard } \\
\text { diet } 1 \\
(\%)\end{array}$ & $\begin{array}{c}\text { Standard } \\
\text { diet } 2 \\
(\%)\end{array}$ \\
\hline Casein & 22 & 22 \\
\hline Soybean oil ${ }^{1)}$ & 6 & 1 \\
\hline Lard & 8 & 10 \\
\hline Salt mixture ${ }^{2)}$ & 4 & 4 \\
\hline Vitamin mixture ${ }^{2)}$ & 0.85 & 0.85 \\
\hline Choline chloride & 0.15 & 0.15 \\
\hline Sucrose $^{3)}$ & 59 & 62 \\
\hline
\end{tabular}

1) Supplemented per $1 \mathrm{~kg}$ of diet with vi$\operatorname{tamin} \mathrm{A}, 3,000 \mathrm{IU}$; vitamin $\mathrm{D}, 300 \mathrm{IU}$; and vitamin $\mathrm{E}, 100 \mathrm{mg}$.

2) Purchased from Tanabe Amino Acid Research Foundation.

3) Each supplement was added at the expense of sucrose.

4) The cholesterol diet 1 and 2 were the standard diet 1 and 2 respectively supple mented with $1 \%$ cholesterol and $0.25 \%$ bile salts (bacto-oxygall, Difco. Lab.).

血清と同様に比色定量した。

\section{実 験 結 果}

植物色素中食品に量的にもっとも多く含まれるのは葉緑素であるが，この色素は比較的不安定であるから安 定な誘導体である銅クロロフィリンナトリウムについて，コレステロール代謝に及畤影響をはじめに検討し た。

初体重 $113 \mathrm{~g}$ の雄ラットに油脂源として大豆油 $6 \%$ とラード $8 \%$ を含む標準飼料 1 ，この飼料とコレステロ 
Table 2 Effects of $\mathrm{Na} \cdot \mathrm{Cu}$-chlorophyllin supplementation on food intake, body weight gain, liver weight, and serum and liver cholesterol levels in male rats fed the hypercholesterolemic diet (Exps. 1 and 2)

\begin{tabular}{|c|c|c|c|c|c|c|c|}
\hline \multirow{2}{*}{\multicolumn{2}{|c|}{$\begin{array}{l}\text { Dietary } \\
\text { Group }\end{array}$}} & \multirow[b]{2}{*}{$\begin{array}{l}\text { No. of } \\
\text { Rats }\end{array}$} & \multirow[b]{2}{*}{$\begin{array}{l}\text { Food } \\
\text { Intake } \\
\text { (g/day) }\end{array}$} & \multirow[b]{2}{*}{$\begin{array}{l}\text { Body } \\
\text { Wt. Gain } \\
\text { (g/day) }\end{array}$} & \multirow[b]{2}{*}{$\begin{array}{c}\text { Liver Wt. } \\
\text { (g) }\end{array}$} & \multicolumn{2}{|c|}{ Total Cholesterol } \\
\hline & & & & & & $\begin{array}{c}\text { Serum } \\
(\mathrm{mg} / 100 \mathrm{~m} l)\end{array}$ & $\begin{array}{l}\text { Liver } \\
\text { (mg/g) }\end{array}$ \\
\hline \multicolumn{8}{|c|}{ Experiment $1^{11}$} \\
\hline A & Standard 1 & 12 & 16. $0 \pm 0.7^{\mathrm{a} 2 \mathrm{~s}}$ & $6.7 \pm 0.3^{\mathrm{a}}$ & $6.7 \pm 0.2^{b}$ & $95 \pm 3^{c}$ & $3.4 \pm 0.1^{c}$ \\
\hline B & Cholesterol 1 & 11 & $15.7 \pm 0.6^{\mathrm{a}}$ & $7.1 \pm 0.4^{\mathrm{a}}$ & $8.7 \pm 0.4^{\mathrm{a}}$ & $145 \pm 15^{\mathrm{a}}$ & 49. $4 \pm 1.6^{\mathrm{a}}$ \\
\hline $\mathrm{C}$ & $\mathrm{B}+1 \%$ Chlorophyllin & 10 & $15.2 \pm 0.7^{\mathrm{a}}$ & $6.7 \pm 0.5^{\mathrm{a}}$ & $7.5 \pm 0.4^{\mathrm{b}}$ & $107 \pm 5^{b}$ & 28. $0 \pm 1.1^{b}$ \\
\hline \multicolumn{8}{|c|}{ Experiment $2^{1)}$} \\
\hline A & Cholesterol 1 & 4 & $15.7 \pm 0.8^{\mathrm{a}}$ & $7.1 \pm 0.7^{\mathrm{a}}$ & $8.1 \pm 0.3^{\mathrm{a}}$ & $144 \pm 23^{\mathrm{a}}$ & 43. $2 \pm 3.7^{\mathrm{a}}$ \\
\hline B & $\mathrm{A}+2 \%$ Chlorophyllin & 4 & $15.6 \pm 0.9^{\mathrm{a}}$ & $7.2 \pm 0.3^{\mathrm{a}}$ & $8.1 \pm 0.2^{\mathrm{a}}$ & $97 \pm 6^{b}$ & 15. $3 \pm 1.1^{b}$ \\
\hline
\end{tabular}

1) The average initial body weight $(\mathrm{M} \pm \mathrm{SE}), 113 \pm 2 \mathrm{~g}$ in Exp. 1 and $126 \pm 5 \mathrm{~g}$ in Exp. 2 and the feeding period, 10 days. Male rats were fasted during one night before sacrifice.

2) Mean \pm S. E. Values within a column not followed by the same alphabetical letter are significantly different $(\mathrm{P}<0.05)$.

ール $1 \%$ と胆汁酸塩 $0.25 \%$ を添加したコレステロール飼料 1 と，さらにこの飼料に銅クロロフィリンナトリウ ムを $1 \%$ 加えた飼料を各々 10 日間投与した（実験 1 )。飼育期間中の飼料摂取量と体重増加量は 3 群で变化が なく,クロロフィリン添加による便の異常も観察されなかった。飼育終了後 1 夜絶食して解剖した時の肝湿重 量では, コレステロール飼料群に比べ $5 \%$ の危険率でクロロフィリン群が低下していた。血清扰よび肝総コレ ステロール量では対照のコレステロール飼料群よりとれぞれ $26.2 \%, 42.8 \%$ 低く, 飼料中のコレステロールと 胆汁酸塩によるコレステロール上昇を明らかに抑制した。実験 1 とほぼ同様の実験条件でクロロフィリン量を $2 \%$ に増加した実験 2 では, 肝重量の低下が認められなかった点が実験 1 と異なった。一方血清と肝コレステ ロール值はそれぞれ対照より $32.6 \%$ ， $65.5 \%$ の低值を示し，クロロフィり ンの量的な増加によりコレステロー ル上昇抑制作用が強く表われた。次 に雌ラットを 2 週間コレステロール 飼料と $2 \%$ クロフィリン添加コレ ステロール飼料で飼育し, 経日的に 血清と肝コレステロール值の変化を 追求した(図1, 図 2)。な拈図表に は示さなかったが，飼育中の体重増 加量は両群で差がなかった。また肝 重量は各飼育期間中クロロフィリン 群で対照よりも軽く，特に14日目で は対照群の $9.0 \pm 0.2 \mathrm{~g}$ に比べ $7.7 \pm$ $0.5 \mathrm{~g}$ と有意に低下していた。血清 コレステロール值（図1）は雌が雄

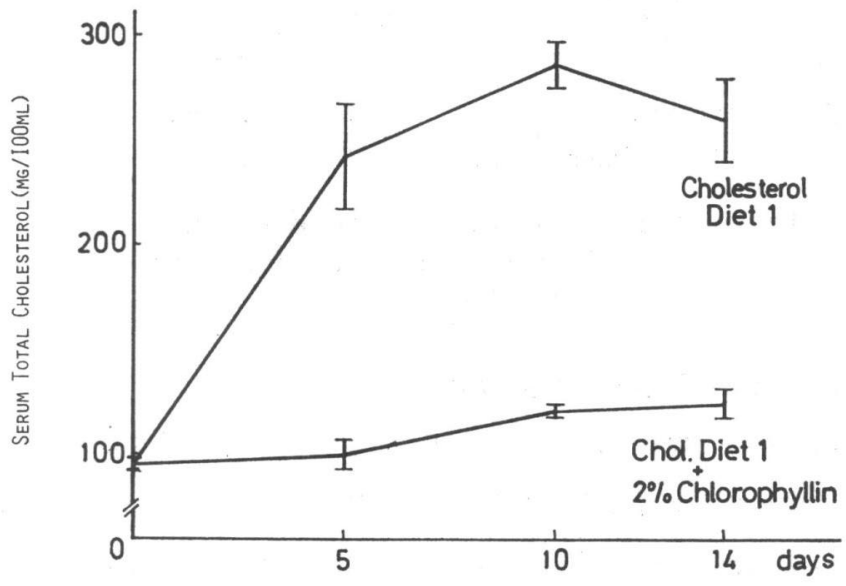

Fig. 1 Time course changes of the serum cholesterol level in rats fed the hypercholesterolemic diets supplemented with or without $\mathrm{Na} \cdot \mathrm{Cu}-\mathrm{chlorophyllin} \mathrm{(Exp.}$ $3)$. Vertical bars indicate \pm SEM of 4 or 5 rats. The average initial body weight, $98 \pm 2 \mathrm{~g}$ and the feeding period, 14 days. Female rats were fasted during one night before sacrifice. 
よりも食慨性コレステロールと胆汁

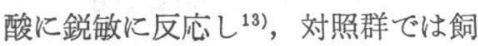
育 5 日目で $242 \mathrm{mg} / 100 \mathrm{ml}$ にも上 升し，ほぽこのレベルが14日目まで 保たれていた。2\%クロロフィリン 添加群では実験 2 の雄の場合と同じ くコレステロール上年は極めてわず かであった。図 2 の肝コレステロー ル量はクロロフィリン群においても かなりの蓄積が見られたものの, 14 日目でも対照群のほほ半分にとどま った。

以上のように過コレステロール血 症を誘発する飼料に銅クロロフィリ

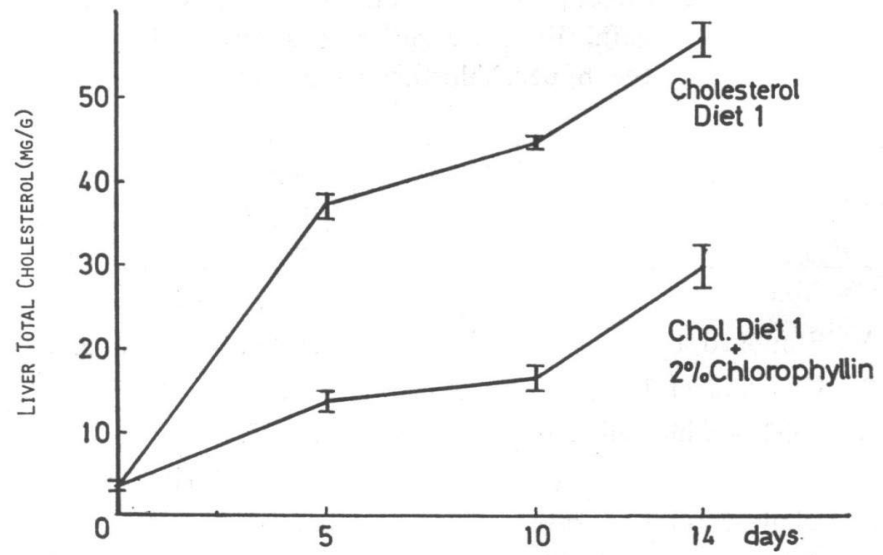

Fig. 2 Time course changes of the liver cholesterol level in rats fed the hypercholesterolemic diets supple. mented with or withont $\mathrm{Na} \cdot \mathrm{Cu}-\mathrm{chlorophyllin} \mathrm{(Exp.}$ 3). Initial body weight and the feeding period were the same as in Fig. 1.

ソを 1 〜 $2 \%$ 添加すると血清及び肝コレステロールの上昇抑制作用が認められたので，次にコレステロールや 胆汁酸塩を含まない標準䬣料にクロロフィリン $2 \%$ を添加して雌ラットを飼育した（実験 4 ）。結果は表 3 に 示したように血清コレステロールは変化なく，肝コレステロールのわずかであるが統計的に有意な減少を認め ただけであった。

Table 3 Effects of $\mathrm{Na} \cdot \mathrm{Cu}$-chlorophyllin addition to the diet without containing cholesterol on body weight gain, liver weight, and serum and liver cholesterol levels in female rats (Exp. 4)

\begin{tabular}{|c|c|c|c|c|c|c|}
\hline & \multirow[b]{2}{*}{$\begin{array}{l}\text { Dietary } \\
\text { Group }\end{array}$} & \multirow[b]{2}{*}{$\begin{array}{l}\text { No. of } \\
\text { Rats }^{1)}\end{array}$} & \multirow[b]{2}{*}{$\begin{array}{c}\text { Body Wt. } \\
\text { Gain } \\
\text { (g/day) }\end{array}$} & \multirow[b]{2}{*}{$\begin{array}{l}\text { Liver Wt. } \\
\text { (g) }\end{array}$} & \multicolumn{2}{|c|}{ Total Cholesterol } \\
\hline & & & & & $\underset{(\mathrm{mg} / 100 \mathrm{~m} l)}{\stackrel{\text { Serum }}{ }}$ & $\begin{array}{l}\text { Liver } \\
(\mathrm{mg} / \mathrm{g})\end{array}$ \\
\hline A & Standard 1 & 8 & $5.3 \pm 0.2^{\mathrm{a} 2)}$ & $4.6 \pm 0.2^{\mathrm{a}}$ & $99 \pm 4^{\mathrm{a}}$ & $3.20 \pm 0.09^{a}$ \\
\hline B & $\mathrm{A}+2 \%$ Chlorophyllin & 7 & $4.8 \pm 0.2^{\mathrm{a}}$ & $4.6 \pm 0.2^{\mathrm{a}}$ & $96 \pm 6^{\mathrm{a}}$ & $2.79 \pm 0.08^{\mathrm{b}}$ \\
\hline
\end{tabular}

1) The average initial body weight $(\mathrm{M} \pm \mathrm{SE}), 84 \pm 3 \mathrm{~g}$ and the feeding period, 10 days. Female rats were fasted during one night before sacrifice.

2) See the footnote of Table 2 .

他の植物性色素として $\beta$-カロチン，ルチン，クェルセチン，キサントフィルを0.5〜 2\%コレステロール飼 料に添加して血清と肝コレステロール值への影響を調べた（表 4 ）。これらの色素は飼料摂取量，成長，肝重 量にはあまり影響を及ぼさず，わずかにキサントフィル $2 \%$ 添加群で体重増加量が 1 日 1 頭当り対照の $7.9 \mathrm{~g}$ から $9.3 \mathrm{~g}$ に増加していただけであった。難吸収性多糖類摂取時によく観察される内容物を含む盲腸重量の増 加は，フラポン系色素であるルチンとクェルセチンに共通してみられ， $\beta$-カロチンとキサントフィルとでは 変化がみられなかった。血清コレステロール值はコレステロール飼料 2 を用いた実験 6 では，雄ラットでも対 照群で $256 \mathrm{mg} / 100 \mathrm{~m} l$ とかなり高值を示した。一方，肝コレステロール值は絶食を負荷しなかったこともあ って実験 5 に比べ全般的に低值を示した。しかし $\beta$ 一カロチン，ルチン，クェルセチンおよびキサントフィル の各添加飼料は血清や肝コレステロールの上升を抑制する効果はなったく認められなかった。 
Table 4 Effects of $\beta$-carotene, rutin, quercetin or xanthophyll addition on food intake, body weight gain, organ weight, and serum and liver cholesterol levels in rats fed the hypercholesterolemic diet (Exps. 5 and 6)

\begin{tabular}{|c|c|c|c|c|c|c|c|c|}
\hline & \multirow[b]{2}{*}{$\begin{array}{l}\text { Dietary } \\
\text { Group }\end{array}$} & \multirow[b]{2}{*}{$\begin{array}{l}\text { No. of } \\
\text { Rats }\end{array}$} & \multirow[b]{2}{*}{$\begin{array}{l}\text { Food } \\
\text { Intake } \\
\text { (g/day) }\end{array}$} & \multirow[b]{2}{*}{$\begin{array}{l}\text { Body Wt. } \\
\text { Gain } \\
\text { (g/day) }\end{array}$} & \multirow[b]{2}{*}{$\begin{array}{l}\text { Liver } \\
\text { Wt. } \\
\text { (g) }\end{array}$} & \multirow[b]{2}{*}{$\begin{array}{l}\text { Caecum } \\
\text { Wt. } \\
\text { (g) }\end{array}$} & \multicolumn{2}{|c|}{ Total Cholesterol } \\
\hline & & & & & & & $\underset{(\mathrm{mg} / 100 \mathrm{ml})}{\text { Serum }}$ & $\begin{array}{l}\text { Liver } \\
(\mathrm{mg} / \mathrm{g})\end{array}$ \\
\hline \multicolumn{9}{|c|}{ Experiment $5^{1)}$} \\
\hline A & Cholesterol 1 & 3 & 15. $2 \pm 0.9^{a 2)}$ & $7.5 \pm 0.3^{\mathrm{a}}$ & $7.8 \pm 0.6^{\mathrm{a}}$ & $1.4 \pm 0.1^{\mathrm{b}}$ & $146 \pm 33^{a}$ & $57.6 \pm 14.6^{a}$ \\
\hline B & $\mathrm{A}+0.5 \% \quad \beta$-Carotene & 4 & $15.9 \pm 0.8^{a}$ & $7.5 \pm 0.5^{\mathrm{a}}$ & $7.9 \pm 0.5^{\mathrm{a}}$ & $1.2 \pm 0.1^{b}$ & $135 \pm 28^{\mathrm{a}}$ & $64.1 \pm 8.4^{\mathrm{a}}$ \\
\hline $\mathrm{C}$ & $\mathrm{A}+2 \%$ Rutin & 4 & $15.4 \pm 0.3^{\mathrm{a}}$ & $7.7 \pm 0.4^{\mathrm{a}}$ & $7.8 \pm 0.4^{\mathrm{a}}$ & $4.7 \pm 0.6^{\mathrm{a}}$ & $202 \pm 58^{\mathrm{a}}$ & $72.8 \pm 8.8^{\mathrm{a}}$ \\
\hline \multicolumn{9}{|c|}{ Experiment $6^{3)}$} \\
\hline A & Standard 2 & 5 & $16.1 \pm 0.7^{\mathrm{a}}$ & $7.1 \pm 0.5^{b}$ & $10.2 \pm 0.2^{c}$ & $2.2 \pm 0.1^{\mathrm{b}}$ & $101 \pm 8^{b}$ & $2.8 \pm 0.1^{\mathrm{b}}$ \\
\hline $\mathrm{B}$ & Cholesterol 2 & 5 & $17.6 \pm 0.7^{\mathrm{a}}$ & $7.9 \pm 0.4^{\mathrm{b}}$ & $12.9 \pm 0.6^{\mathrm{a}, \mathrm{b}}$ & $1.9 \pm 0.1^{b}$ & $256 \pm 25^{\mathrm{a}}$ & $29.9 \pm 0.9^{a}$ \\
\hline $\mathrm{C}$ & $\mathrm{B}+2 \%$ Quercetin & 5 & $17.4 \pm 0.4^{\mathrm{a}}$ & $8.1 \pm 0.2^{\mathrm{b}}$ & $11.5 \pm 0.3^{b}$ & $4.2 \pm 0.4^{\mathrm{a}}$ & $282 \pm 37^{a}$ & $34.7 \pm 1.9^{a}$ \\
\hline $\mathrm{D}$ & B+2\% Xanthophyll & 5 & $18.2 \pm 0.6^{\mathrm{a}}$ & $9.3 \pm 0.3^{\mathrm{a}}$ & $13.4 \pm 0.4^{\mathrm{a}}$ & $2.1 \pm 0.2^{\mathrm{b}}$ & $235 \pm 18^{a}$ & $34.0 \pm 2.3^{\mathrm{a}}$ \\
\hline
\end{tabular}

1) The average initial body weight $(\mathrm{M} \pm \mathrm{SE}), 100 \pm 2 \mathrm{~g}$, and the feeding period, 10 days. Male rats were fasted during one night before sacrifice.

2) See the footnote of Table 2 .

3) The average initial body weight $(M \pm S E), 110 \pm 3 \mathrm{~g}$, and the feeding period, 8 days. Male rats were not fasted before sacrifice.

4) Caecum weight includes its contents.

\section{考察}

各被験色素が飼料摂取量および体重増加量に及ぼす影響は少なく，わずかにキサントフィル $2 \%$ 添加飼料で 体重が対照のコレステロール飼料群よりも却って増加したにすぎないが，なぜ体重が増加したかその理由は明 らかでない。銅クロロフィリン塩の $2 \%$ 摂取でも，飼料にコレステロールと胆汁酸が有る無しにかかわらず著 しい変化は見出せなかったため，本報の実験条件下では成長阻害の心配はないものと推定される。肝重量はコ レステロール飼料で標準飼料よりも増加し，クロロフィリン投与群ではこの肝重量の増加が抑制される（実験 1，3）か，もしくは同レベルに保たれていた（実験 2 ）。他の色素ではクェルセチンで肝重量の低下傾向が 観察されたが，色素は多糖類 ${ }^{3)}{ }^{17)}$ の場合よりも肝重量への影響は少ないようである。内容物を含む盲腸重量の

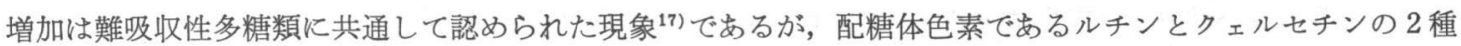
のフラボン系色素にも同様に惹起されたことは興味深い。多糖類と配糖体色素は共に構造中に糖を含んでいる ので, これらの糖の分解と盲腸腫大とは何らかの関連性を有することが推定される。

1933年に Blumer らは家束に30日から98日間コレステロールを摂取させても，週に 4 回飼料に $10 \mathrm{~g}$ のク ロロフィル (Chlorosan) を加えることにより血清コレステロールの上昇を抑制できると報告した10)。しかし Altschul らは同じく家鬼に 1 日 $0.25 \mathrm{~g}$ の脂溶性もしくは水溶性のクロロフィルを経口的に投与しても血清コ レステロールは変化しなかったとし, 前者らとの実験結果が異なっている。この 2 つ報文ではクロロフィル そのものを用いたのか, それとも誘導体を用いたのか明らかでなかった。また飼料条件も後者では明記してい ないが，ウサギの血清コレステロール值から判断すると正常值に近く無コレステロール飼料を用いたものと推 定される。本研究の銅クロロフィリンについての実験では，加コレステロール飼料の実験結果（実験 1 〜 3 ） は Blumer らの知見 ${ }^{10)}$ とよく一致し，一方無コレステロール飼料の実験結果 (実験 4 ) は Altschul ら ${ }^{11)}$ の 成績とよく一致した。従って飼料中にコレステロール（と胆汁酸塩）を加えるか否かによって Blumer らと 
Altschul らの結果に差異が生じたものと推定される。近年, 土屋はシロネズミにコレステロールとクロロフ イルや銅クロロフィリンを同時に摂取させても血中コレステロールの上萛は抑党られなかったとしている ${ }^{12)}$ しかし, 土屋の研究 ${ }^{12)}$ では投与量が 1 日 $25 \mathrm{mg}$ と本研究の投与量の $1 / 6$ 以下であり, あまりにも少量すぎた ため, ネガティブでめったものと思われる。従って, 銅クロロフィリンナトリウムとしては今回初めて脱コレ ステロール作用が確認されたものといえよう。

一方クロロフィリンが肝コレステロール量に及ぼす影響は従来まったく研究されていなかった。外因性コレ ステロールは肝臓一血液プールとくに肝蔵にもっとも顕著に蓄積され(図 2 ), 脂肪肝形成にも関連が深いため 肝コレステロール量の変化は血清のそれに劣らず重要な指標とされている。今回銅クロロフィリンは肝臓への 食饂性コレステロールの蓄積にも血清同様抑止効果を示した。即ちシロネズミの性差にかかわりなく飼料中 2 \%の搨取で明らかに対照のほぼ1/2〜1/3に抑えられた。また投与量が $1 \%$ の場合でも血清と共に肝コレステロ ールの段階的な低下作用が認められた。無コレステロール飼料へのクロロフィリン $2 \%$ 添加は肝臓では血清と 異なり統計的に有意の差が認められたが, コレステロール量の減少はわずかであるので, 飼料条件や絶食負荷 などのコレステロール合成系に変化を及ぼす上うな条件変動ではこの結果は変化しうるものかるしれない。

血中コレステロール低下物質の作用機序は大別して, (1)生体内コレステロールの合成阻害, (2)他組織からの血 液へのコレステロールの移動の制限, (3)消化管内に怙けるコレステロールまたは胆汁酸塩の吸収阻害（排泄促 進）の 3 つが，考えられる。(1)の合成阻害は外因性コレステロール自体でも誘起されるため, 無コレステロー ル飼料に被験物質を加えて飼育したときのみ血中や肝コレステロールが低下するが，クロロフィリンは逆に飼 料にコレステロールと同時添加したときに著しく血清と肝コレステロールが低下したため, この作用機序では ないと思われる。次に(2)の組織一血液間の移動制限による脱コレステロール物質とみなされているェリタデニ ンは飼料中コレステロールの有無に拘らず肝コレステロールは変化しない18)。この点は今回のクロロフィリン の成績と大きく異なる区別点である。次にわれわれはクロロフィリンの消化吸収が極めて悪く大部分が䨢中に 排泄されることを観察している。この消化吸収されにくいとい5特性は(3)の吸収阻害に属すると推測されてい るコンニャクマンナンやクルクミンと共通しておうう, しかも食䬺性コレステロールの血液や肝臓への蓄積を抑 制するが，無コレステロール飼料に添加しても血中や肝コレステロールの著しい低下は招こさないという点も 極めてよく類似している。詳しい作用機序の研究は今後さらに追求したいが以上考察してきたようにクロロフ イリンの脱コレステロール作用は(3)のコレステロールもしくは胆汁酸の吸収阻害の可能性が強いものと想定さ れる。

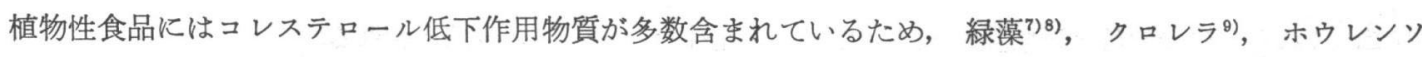

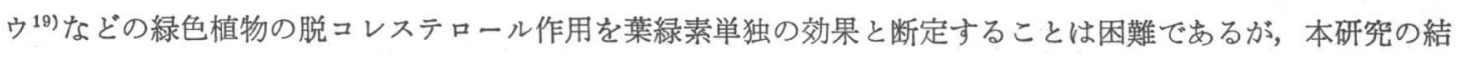
果から少なくともとの一因子である可能性は強くなった。銅クロロフィリンは食品添加物として大量に常用さ れて㧍り, 脱コレステロール作用といら新しい生理効果の解明は動脈硬化の予防と治療にも利用される道を開 くものと期待される。

要 約

食品成分から脱コレステロール物質を検索する目的でシロネズミのコレステロール代謝に及ぼす植物性色素 の影響を調べた。

1）葉緑素の水溶性誘導体である銅クロロフィリンナトリウム塩に過コレステロール血症シロネズミの血清 
拉よび肝コレステロール値の低下作用が認められた。

2）無コレステロール飼料にクロロフィリンを添加しても血清コレステロール值には変化がなかったが，肝 コレステロール值は若干低下した。

3） $\beta$-カロチン，ルチン，クェルセチン，キサントフィルの 0.5 ～ $2 \%$ 添加では脱コレステロール作用は, 観察されなかった。

終りに貴重な試料を提供された日新化学(秼並びに田辺製薬秝に厚くお礼申し上げます。

（本研究の概要は第24回日本栄養・食糧学会総会 (1970) にて報告した。)

文献

1) Siperstein, M. D. et al : Science, 111, 386 (1953)

2) Cayen, M. N. : J. Lipid Res., 12, 482 (1971)

3）辻啓介, 他：栄養学雑誌, 26, 113 (1968)

4) 辻啓介, 他 : 栄養学雑誌, 31, 152 (1973)

5）辻啓介, 他：栄養と食糧, 27, 405 (1974)

6) Subba Rao, D., et al : J. Nutr., 100, 1307 (1970)

7）金田尚志，他：Bull. Jap. Soc. Sci. Fish., 29, 1,020 (1963)

8）金田尚志，他：Bull. Jap. Soc. Sci. Fish., 31, 1,026 (1965)

9) Kondratiev, Y. I., et al : Voprosy Pitaniya, 25, 9, 14 (1966)

10) Blumer, C., et al : Arch. f. Exp. Path. Pharmak., 173, 42 (1933)

11) Altschul, V. R. and T. A. Smart : Arzneimittel Forsch, 11, 762 (1961)

12) Tsuchiya, Y. : Proc. Intl. Seaweed Symp., 6, 747 (1969)

13）辻 啓介, 鈴木慎次郎 : 栄責学雑誌, 30, 235 (1972)

14）辻 綮介, 他: 栄養学雑誌, 33, 51 (1975)

15) Sobel., C. and Fernandez, A. : Clin. Chem., 12, 739 (1966)

16) Sperry, W. M. and Webb, M. : J. Biol. Chem., 187, 97 (1950)

17) 辻 啓介, 他 : 栄養学雑誌, 32, 155 (1974)

18）辻 悦子, 他: 栄養学雑誌, 33, 9 (1975)

19）入谷信子 : 栄養と食糧, 22, 258 (1969)

（受付 : 昭和50年 7 月 25 日） 